Letrônica, Porto Alegre, v. 7, n. 2, p. 884-903, jul./dez., 2014

\title{
A TRAVESSIA DO RIO MUDANDO IDENTIDADES CULTURAIS CAUSANDO DES-LOCAMENTOS - UM ESTUDO SOBRE A OBRA DE CARYL PHILLIPS
}

\author{
THE CROSSING RIVER CHANGING CULTURAL IDENTITIES CAUSING \\ DISPLACEMENTS - A STUDY ON THE WORK CARYL PHILLIPS
}

\author{
Marcio da Silva Oliveira* \\ Alba Krishna Topan Feldman**
}

\begin{abstract}
Resumo: 0 objetivo desse artigo é demonstrar, através do romance $A$ travessia do rio, de Caryl Phillips, as situações de (não) pertencimento e de fragmentação do sujeito causadas pela diáspora no período da escravidão. Trata-se de um esforço por analisar a formação identitária diaspórica das personagens centrais do romance e as suas consequências sociais e culturais nos caminhos do Atlântico. Sob a perspectiva da diáspora e do pós-colonialismo, a análise se estrutura em quatro autores essenciais: Stuart Hall, no qual se pode entender o sentido da diáspora africana; Avtar Brah, que focaliza o movimento diaspórico sob o prisma da ideia de lar e pertencimento; Paul Gilroy, que destaca a identidade negra formada no entre-lugar, em trânsito pelos caminhos do Atlântico; e Frantz Fanon, que analisa a fragmentação do sujeito africano devido à diáspora forçada. 0 resultado disso são as vozes da cultura africana que, pelo movimento diaspórico, continuam ecoando por todas as partes do Atlântico.
\end{abstract}

Palavras-Chave: Diáspora, Identidade, Pertencimento, Fragmentação do Sujeito.

\begin{abstract}
The aim of this paper is to demonstrate, through the novel Crossing the River by Caryl Phillips, situations of (not) belonging and fragmentation of the subject caused by the diaspora in the period of slavery. This is an effort to examine the diasporic identity formation of the central characters of the novel and its social and cultural consequences in the ways of the Atlantic. From the perspective of the diaspora and postcolonialism, the analysis is divided into four main authors: Stuart Hall, in which one can understand the meaning of the African Diaspora, Avtar Brah, which focuses on the diasporic movement through the prism of the idea of home and belonging, Paul Gilroy, highlighting black identity formed in-between, in transit through the paths of the Atlantic, and Frantz Fanon, who analyzes the fragmentation of the African subject due to the forced diaspora. The result are the voices of African culture that the diasporic movement, still echo all over the Atlantic.
\end{abstract}

Keywords: Diaspora, Identity, Belonging, Fragmentation of the Subject.

\footnotetext{
* Doutorando em Letras, pela Universidade Estadual de Maringá - PR (2014). Mestrado em Letras, na área de concentração Estudos Literários (2011). Bolsista da CAPES, com projeto de pesquisa voltado ao campo da Literatura e Historicidade: a influência do teatro épico-dialético, de Brecht, no moderno teatro brasileiro.

** Doutora em Letras, pela UNESP, de São José do Rio Preto (2010), e complementação na Louisville University, nos Estados Unidos (2009). Atualmente é docente do Programa de Pós-Graduação em Letras, pela Universidade Estadual de Maringá.
} 


\section{Introdução}

Segundo Stuart Hall (2003), nos tempos modernos, principalmente a partir de 1942, a cultura mundial vem se desenvolvendo de modo diaspórico. A convivência entre diferentes culturas em um mesmo território, a fusão de movimentos culturais distintos que tanto influenciam a música, a literatura e outras artes e, principalmente, a consolidação do multiculturalismo em âmbito global são, de certa forma, resultados da dispersão forçada ou incentivada nos caminhos da história.

Nesse artigo, destacam-se as consequências da diáspora africana para a reformulação cultural nos caminhos do Atlântico, que envolvem o continente africano, o europeu e o americano. Para isso, propõe-se a análise da identidade das personagens centrais do romance A travessia do rio, de Caryl Phillips. Essas personagens, que resgatam momentos importantes da diáspora africana, simbolizam na obra a sensação de não-pertencimento, o dilaceramento do sujeito e os traumas provocados pela saída forçada do local de origem.

Num primeiro momento, propomos uma conceituação do termo diáspora e seus desdobramentos na teoria de autores africanos que, de certa forma, tiveram suas vidas também marcadas pela diáspora. Para isso, fundamentamos a teoria no pensamento de Stuart Hall, Paul Gilroy, Avtar Brah e Frantz Fanon. Com olhares bastante peculiares sobre o sujeito diaspórico, esses autores nos auxiliam na análise das personagens do romance, uma vez que tratam de conceitos relacionados ao pertencimento, à fragmentação do sujeito e à identidade construída no entre-lugar¹.

Para a análise propriamente dita, destacamos no romance a trajetória das três personagens centrais: Nash, Martha e Travis. Marcados pelo comércio da escravidão e dispersos pelos continentes circundantes do Atlântico, os três irmãos são exemplos da identidade construída em trânsito. Eles levam consigo as marcas do abandono e da

\footnotetext{
${ }^{1}$ Eliana Lourenço de Lima Reis e Gláucia Renate Gonçalves, tradutoras de The Location of Culture (O Local da Cultura, de Homi Bhabha) utilizaram o termo entre-lugar, cunhado por Silviano Santiago, para traduzir o termo In-between na acepção que utilizamos nesse artigo: um espaço simbólico e/ou geográfico híbrido que, ao mesmo tempo em que evidencia conflitos entre diferentes culturas e a perda da identidade, enseja negociações e mudanças.
} 
outremização ${ }^{2}$ e veem suas identidades dilaceradas pelas perdas e pela sensação de nãopertencimento, estrangeiros tanto na pátria de origem quanto na de acolhimento.

\section{0 sujeito diaspórico}

Paul Gilroy (2001), no livro O Atlântico Negro, propõe um debate acerca da formação da identidade cultural africana mediante a história do Atlântico Negro e da diáspora africana. Essa diáspora, em sua obra, constitui não somente uma dispersão catastrófica, mas um processo que redefine a mecânica histórica e cultural do pertencimento. Rompe com o poder do território para determinar o conceito de identidade. Assim, a ideia do território de origem como lugar antropológico de resgate da identidade cede espaço à formação identitária em trânsito.

Partindo dessa ideia, destaca-se o pensamento de Avtar Brah (1996), para quem o conceito de diáspora gera uma tensão entre o discurso do 'lar' e o da 'dispersão', inscrevendo o desejo de voltar para casa ao mesmo tempo em que critica o discurso de origem fixa. Para Brah, "esse conceito deve ser visto para se referir a 'genealogias' historicamente contingentes ou como mapeamento conceitual que desafia a busca por origens absolutas". (BRAH, 1996, p. 193). Trata-se da problematização do desejo de pertencimento e de lar em situação de diáspora.

Para Brah (1996), as diásporas devem ser entendidas, não somente pelo seu lado negativo, de saída violenta do lar de origem e dispersão, mas, potencialmente, como locais de novos recomeços, terrenos de contestações políticas e culturais, onde memórias individuais e coletivas colidem, se reagrupam e ganham novas configurações. As diásporas, desse modo, provocam significativas mudanças no modo como se imagina as comunidades de pertencimento e torna complexa a ideia de 'lar'. "Os processos de formação de identidade diaspórica são exemplos por excelência de que a identidade é sempre plural e no processo" (BRAH, 1996, p. 194). Sendo assim, a ideia de lar e pertencimento não está necessariamente ligada à ideia de pátria, de local de origem, mas

\footnotetext{
20 termo 'outremização' (othering) foi cunhado por Gayatri Spivak em um estudo de 1985 para descrever um processo pelo qual o discurso imperial cria seus sujeitos. 0 outro é o excluído ou o sujeito dominado pelo discurso de poder. Na explicação de Spivak, a outremização é um processo dialético porque o colonizador Outro (o grande outro) é estabelecido ao mesmo tempo em que seus colonizados (outros) são produzidos. São termos relacionados o adjetivo 'outremizado' (a) e o verbo 'outremizar'.
} 
pode estar ausente no local de origem da identidade, ou ser criada em ambientes de extrema mobilidade e fluidez, distante deste ponto de origem.

Tal pensamento é indispensável à análise da identidade africana constituída pelos movimentos diaspóricos em A travessia do rio, onde as ideias de lar e pertencimento norteiam a trajetória das personagens pelos caminhos do Atlântico.

A identidade africana, constituída no entre-lugar, faz com que Paul Gilroy (2001), em seu Atlântico Negro, propunha um modo transnacional de refletir sobre a experiência negra no mundo. Para isso, ele parte da constatação de que as comunidades negras de todos os lados do Atlântico experimentaram um constante intercâmbio no seu processo de formação cultural. Tal experiência determinou a formação de uma identidade fragmentada refletida no não-pertencimento, tanto na pátria de origem quanto na comunidade para onde foram levados.

Em A Travessia do Rio a questão do pertencimento é constantemente retomada. Nash, Martha e Travis vivem os conflitos inerentes aos indivíduos que se veem forçados a abandonar sua comunidade de origem e buscam incansavelmente o pertencimento em outros territórios. Mas, afinal, qual a verdadeira identidade dessas personagens? Quando um lugar de residência pode se tornar um lar?

São essas questões que norteiam a análise aqui proposta e auxiliam no entendimento acerca do intercâmbio cultural realizado pelas comunidades negras nos arredores do Atlântico. Seguindo a teoria de Brah (1996), em seu livro Cartographies of Diaspora, essas questões podem ser respondidas segundo os conceitos de lar e pertencimento. Por um lado, o termo 'lar' é ligado a um lugar mítico do desejo que está na imaginação diaspórica, um lugar de retorno. Por outro lado, é também a experiência viva local do sujeito, onde a vivência é mediada pelas relações sociais historicamente especificadas em seu cotidiano. A questão acerca do lar e do pertencimento está ligada, assim, ao modo como os processos de inclusão e exclusão são experimentados pelo sujeito diaspórico e isso está bastante presente no romance de Phillips.

Publicado em 1994 e cujo enredo se estende por mais de 200 anos da diáspora africana, $A$ travessia do rio narra a história de três irmãos vendidos pelo próprio pai e entregues à escravidão. Nash, Travis e Martha enfrentam jornadas distintas em busca da própria identidade fragmentada, usurpada pelo poder colonial. $\mathrm{O}$ autor coloca em jogo a trajetória de uma família marcada pelos descaminhos da escravidão. Torna-se, assim, 
pertinente uma análise que destaque na obra a identidade em trânsito teorizada por Gilroy e a ideia de pertencimento.

No início do romance já se percebe os descaminhos da diáspora, quando o pai, devido ao fracasso da colheita, decide vender os filhos:

Vendi meus filhos [...] Fiquei olhando enquanto eles se abraçavam e olhavam para o forte, onde tremulava no alto uma bandeira estrangeira. [...] Eu os despachei nesse ponto onde o afluente se divide e parte em todas as direções a caminho do mar (PHILIPS, 2011, p. 7).

Assim, os três são conduzidos a lugares e contextos diferentes e iniciam uma difícil trajetória, uma tentativa de resgatar a própria identidade. Nash é criado pelo colonizador que lhe confere o status de cristão e, a seguir, retorna ao continente africano como missionário numa tentativa de resgatar suas raízes. Martha é uma das primeiras integrantes das caravanas para o velho oeste americano no século XIX. Seu objetivo maior é reencontrar a filha e o marido, afastados por ocasião de sua venda. Travis, já na Segunda Guerra Mundial, é um soldado que exerce seu cargo em uma aldeia da Inglaterra e que se casa com uma inglesa branca com quem tem um filho que nem chega a conhecer.

Ao contar a trajetória das três personagens, Phillips resgata mais de 200 anos da diáspora africana e, por isso, historicamente, seria impossível que as personagens centrais fossem filhas biológicas do mesmo pai. Porém, metaforicamente, tornam-se símbolos da população negra diaspórica em períodos diferentes da história. Elas se tornam filhas simbólicas do desterro africano, das circunstâncias da diáspora e que, apesar dos traumas sofridos, levam a cultura africana para todos os lugares, inclusive a Europa e a América, destacados no romance.

Três personagens em situações diferentes de diáspora e, com elas, o retrato de uma cultura marcada por estruturas transnacionais. Essas estruturas possibilitaram ao povo negro, no movimento diaspórico africano, formar uma cultura não exclusivamente africana, americana, britânica ou caribenha, mas todas elas ao mesmo tempo. 


\subsection{Identidades em trânsito: diáspora, lar e pertencimento}

A palavra diáspora é, normalmente, empregada na definição do deslocamento, forçado ou incentivado, de grandes massas populacionais de uma determinada região originária para várias outras regiões de acolhimento distintas. Advindo do verbo grego speiro, que significa semear e disseminar, esse termo também é utilizado para apontar a dispersão de um povo sobre o mundo. Stuart Hall, partindo da ideia de dispersão utiliza o termo diáspora para teorizar a formação identitária dos povos colonizados na África e espalhados pelo resto do planeta, em especial, o povo caribenho. Para ele,

A questão da diáspora é colocada principalmente por causa da luz que ela é capaz de lançar sobre as complexidades, não simplesmente de se construir, mas de se imaginar a nação (nationhood) e a identidade caribenhas, numa era de globalização crescente. (HALL, 2003, p. 25-26).

O indivíduo diaspórico é aquele cuja identidade se constrói em trânsito, entre seu local de origem e o local para onde é destinado. Analisar o sujeito trazido de terras africanas por ocasião da escravidão e espalhado por todas as partes de Atlântico é ultrapassar perspectivas nacionais no processo de significação cultural.

Sendo assim, Paul Gilroy (2001), em seu Atlântico Negro propõe uma visão de cultura não mais baseada em conceitos como o nacionalismo e etnocentrismo, advindos dos povos europeus, americanos e africanos. A identidade cultural é vista aqui não como pura e homogênea, mas se constrói no processo de mistura entre os cidadãos da metrópole e o sujeito diaspórico.

A diáspora, importada de fontes judaicas para o processo formativo da cultura negra, encontra-se no núcleo da análise de Gilroy. Para o autor, ela é a grande responsável pela redefinição da mecânica cultural e histórica do pertencimento, rompendo com a máxima de que o território é efetivamente o responsável pela determinação da identidade. Gilroy lança sua crítica contra a ideia de uma formação identitária autêntica, pura, homogênea, estável e enraizada, veiculada principalmente pelas diversas formas de nacionalismo, seja da África, da Europa ou da América. 0 Atlântico é o local essencial da formação da identidade, sendo ela, portanto, transnacional. Assim entendendo a diáspora, compreende-se a identidade não sob a tutela da nacionalidade ou da raça, mas essencialmente como "formas geopolíticas e 
geoculturais de vida que são resultantes da interação entre sistemas comunicativos e contextos que elas não só incorporam, mas também modificam e transcendem" (GILROY, 2001, p. 25).

Tal situação cria uma nova topografia de lealdade que desconsidera os pressupostos do Estado-nação e abre-se a novas formas de identificação entre o indivíduo no espaço e no tempo. 0 Atlântico tomado como metáfora, assim como o navio tornado símbolo da identidade em trânsito ou como afirma o próprio Gilroy (2001, p. 60) "meios vivos pelos quais se uniam os pontos naquele mundo atlântico", remetem ao sentimento de desterritorialização da cultura, opondo-se ao conceito de cultura homogênea, fechada sob os limites de uma fronteira, um território. É a transcendência, ao mesmo tempo, do nacionalismo e do etnocentrismo e a constituição da identidade em trânsito.

A compreensão da formação identitária do sujeito diaspórico proposta pela análise de Gilroy nos oferece um ponto de partida para o entendimento da formação da personalidade desse sujeito, personalidade essa fragmentada e dilacerada pela sensação de não-pertencimento. Tais argumentos serão indispensáveis à análise do romance de Caryl Philips, objetivo do presente artigo.

Segundo Roland Walter:

A existência diaspórica designa um entre-lugar caracterizado por desterritorialização e a implícita tensão entre a vida aqui, e tanto a memória quanto o desejo por lá. Nesse sentido, os que vivem na diáspora (migrantes, imigrantes, exilados, refugiados, Gastarbeiter, entre outros) compartilham uma dupla se não múltipla consciência e perspectiva caracterizadas por um diálogo difícil entre vários costumes e maneiras de a ver e agir. (WALTER, 2006, p. 4).

A identidade construída em trânsito nos (des)caminhos do Atlântico é constituída de consciência dupla ou múltipla, o que, inevitavelmente conduz o sujeito à fragmentação da própria personalidade. Frantz Fanon, em seu livro Pele Negra, Máscaras Brancas descreve a situação do negro quando retirado de sua cultura originária e colocado frente a frente com seu dominador, no território dele. A partir desse momento, ele passa a viver uma situação de dilaceramento e anulação da própria identidade, restando-lhe apenas a tentativa de igualar-se com seu dominador como única maneira de fugir da inferioridade provocada pela imposição da colonização 
europeia. E assim, "pouco a pouco se forma e se cristaliza no negro uma atitude, um hábito de pensar e perceber que são essencialmente brancos" (FANON, 2008. p. 132).

0 negro veste a máscara branca para não se sentir outremizado, adotando padrões de comportamento típicos do dominador. Enquanto ser colonizado, ele tenta assimilar a cultura do outro em busca de reconhecimento. 0 sujeito dominador, aproveitando-se disso, propõe ao colonizado uma 'libertação' do mundo mítico em que vivia até então, falsificando sua história e criando outra ancorada no discurso dominante da metrópole. "Os indivíduos que pensam ou falam fora dos parâmetros do discurso dominante são definidos como loucos ou reduzidos ao emudecimento" (BONNICI, 2005, p. 224).

Assim, o negro é colocado para fora da própria história e, mesmo buscando reconhecimento através da assimilação cultural do outro, o olhar do branco sobre ele denuncia sua negritude, o que comprova seu não-pertencimento à cultura na qual foi forçadamente inserido. Por outro lado, ao tentar resgatar as origens, retornando à sua cultura primordial, o sujeito percebe-se estrangeiro também ali, o que dilacera ainda mais sua identidade e, consequentemente, agrava a sensação de não-pertencimento.

Como veremos à frente, o romance de Philips retrata com nitidez essa situação de constante diáspora na qual o sujeito negro se encontra. 0 indivíduo posiciona-se no entre-lugar, se sentido deslocado tanto no espaço de origem quanto no espaço de 'acolhimento'. Como bem destacado por Stuart Hall (2003), a formação de posições de identidade no sujeito diaspórico acarreta a construção de uma identidade dupla ou até mesmo múltipla. 0 sujeito não se sente totalmente inserido no ambiente estrangeiro e, por isso, sente a necessidade de um regresso à pátria originária. Ao regressar, contudo, esse sujeito encara uma dura realidade, como sublinha Hall:

Não podemos jamais ir pra casa, voltar à cena primária enquanto esquecidos de nossos começos e 'autenticidade', pois há sempre algo no meio (between). Não podemos retornar a uma unidade passada, pois só podemos conhecer o passado, a memória, o inconsciente através dos efeitos. (HALL, 2003, p. 27).

O retorno à pátria de origem jamais será o mesmo para o sujeito diaspórico e, por isso, a problemática ligada à ideia de lar e de pertencimento o acompanhará por toda a vida. O próprio Stuart Hall, jamaicano que viveu grande parte da vida na Inglaterra, filho 
de pai negro e mãe 'branca local', experimentou essa sensação de não-pertencimento, como se pode notar no trecho abaixo:

\begin{abstract}
Esta não era a Jamaica onde eu tinha crescido. Por exemplo, tinha se tornado culturalmente uma sociedade negra, uma sociedade pós-escravocrata e póscolonial, enquanto que eu havia vivido lá no final da era colonial [...]. Paradoxalmente, eu tinha a mesma relação com a Inglaterra. Tendo sido preparado pela educação colonial, eu conhecia a Inglaterra de dentro. Mas não sou nem nunca serei inglês. Conheço intimamente os dois lugares, mas não pertenço completamente a nenhum deles. E esta é exatamente a experiência diaspórica, longe o suficiente para experimentar o sentimento de exílio e perda, perto o suficiente para entender o enigma de uma "chegada" sempre adiada. (HALL, 2003, p. 415).
\end{abstract}

Desse modo, assim como a teoria do Atlântico Negro, de Paul Gilroy, da fragmentação da identidade africana, de Frantz Fannon e da ideia de lar e pertencimento de Avtar Brah, Stuart Hall, ao relatar sua experiência diaspórica, apresenta grande contribuição aos estudos de identidades construídas no entre-lugar, no entrechoque de culturas distintas. 0 entre-lugar provocado pelo sentimento de não-pertencimento transforma-se em espaço de formação de identidades e transforma radicalmente as relações sociais em todos os espaços do Atlântico. Ele coloca o sujeito diaspórico à deriva, o que pode trazer drásticas consequências à sua existência, como é o caso de Nash, personagem de $A$ travessia do rio, cuja vida é marcada tragicamente pela sensação de não-pertencimento.

Como se nota, as teorias de Paul Gilroy, Frantz Fanon, Avtar Brah e Stuart Hall tornam-se essenciais à proposta desse artigo: a análise do sujeito diaspórico no romance de Caryl Philips. Para tal análise se leva em conta a formação identitária das personagens centrais em seu trânsito pelos caminhos do Atlântico. Essas personagens tornam-se, no romance, produtos da diáspora, "devem aprender a habitar, no mínimo, duas identidades, a falar duas linguagens culturais, a traduzir e a negociar entre elas" (HALL, 2005. p. 89).

\title{
2 Análise de A travessia do rio
}

No romance $A$ travessia do rio, Caryl Phillips ousadamente resgata mais de 200 anos da diáspora africana. Nascido em St. Kitts, no Caribe, Phillips se mudou para a Inglaterra quando tinha apenas quatro meses e estudou Literatura Inglesa na 
Universidade de Oxford. Atualmente residindo nos Estados Unidos, o escritor constrói seu romance de modo peculiar, sustentando-o em um painel de vozes que narram a história de uma família cujos laços foram violentamente quebrados por causa da escravidão. No ano de 1753, auge do tráfico negreiro pelas águas do Atlântico, um pai, desesperado pelo fracasso da colheita, decide vender os três filhos, que são entregues a um navio inglês com destino à América:

\begin{abstract}
Uma tolice desesperada. A colheita fracassou. Vendi meus filhos [...] fiquei olhando enquanto eles se abraçavam e olhavam para o forte onde tremulava uma bandeira estrangeira [...] À distância estava o navio ao qual eu logo iria condená-los [...] Apenas três crianças. Eu as despachei nesse ponto onde o afluente se divide e parte em todas as direções a caminho do mar. (PHILIPS, 2011, p. 7).
\end{abstract}

Simbolicamente separados no tempo, os três irmãos levados a continentes e épocas diferentes resgatam a história dos filhos da escravidão. Suas vozes discursivas denotam o fato de que, embora tenham conquistado o status de cidadãos livres em terras estrangeiras, continuam de certa forma, escravizados seja pelo poder 'civilizatório' da religião do colonizador (Nash), seja pela dura separação de entes queridos e a quebra de laços que remontam à origem (Martha) seja pela personalidade marcada pelos horrores da guerra (Travis).

Para contar a história dos três irmãos e, em consequência, resgatar os (des) caminhos da diáspora, Philips não se ateve à estrutura romanesca tradicional, a uma linha narrativa reta sem aprofundamento psicológico das personagens, como as primeiras obras reconhecidas como romance, mas apresentou estruturas narrativas diferentes a cada um dos personagens. Somente no caso de Martha é que o autor apresenta uma sequência narrativa linear, onde o narrador, em terceira pessoa, conta a peregrinação da personagem rumo à Costa Oeste dos Estados Unidos, em busca de notícias de seus entes queridos.

A história de Nash é apresentada ao leitor mediante cartas enviadas a seu exsenhor, onde a personagem relata o mal sucedido retorno à pátria de origem. No caso de Travis, a narrativa assume a estrutura de diário, onde os fatos narrados são acompanhados de datas e contextualizados no período que corresponde à Segunda Guerra Mundial. 
Somam-se a essas construções um preâmbulo, com foco em primeira pessoa, onde o pai lamenta a venda dos próprios filhos em nome da sobrevivência e um diário de viagem de um vendedor de escravos que, a bordo de um navio negreiro, divide seu tempo entre a atividade cruel do tráfico humano e a saudade da esposa.

Dentro dessa estrutura adotada por Phillips para seu romance desenha-se um rico painel de personagens que bem delineiam os rumos e as consequências da diáspora nos caminhos do Atlântico. Em uma trama onde as ideias de lar e pertencimento se inserem no contexto da diáspora as vozes que ecoam são de personagens alçados à categoria de heróis e cujas trajetórias trágicas refletem o dilaceramento provocado pela retirada forçada de seus locais de origem, de sua cultura original.

\subsection{Nash, marcas do não-pertencimento}

A travessia do rio, como já citado acima, inicia-se com um preâmbulo, no qual se narra a história de um pai que, ao ver-se cercado pela miséria, decide vender os próprios filhos à escravidão. Três filhos, três destinos, três identidades formadas sob as águas do Atlântico. Nash, Martha e Travis tornam-se, a partir disso, modelos do sujeito diaspórico constituído nos entrechos da escravidão. Phillips utiliza-se de recursos narrativos diversos para contar a história de cada um dos irmãos e seus destinos após a quebra do laço com a pátria de origem.

O segundo capítulo do romance, intitulado A Costa Pagã retrata a trajetória de Nash Williams, primeiro dos irmãos, renomado professor e dotado de grandes talentos. Educado como cristão, hábil na escrita e na leitura, retorna à Libéria para resgatar suas origens, como afirma o narrador já no início: "Nash Williams, enviado à Libéria sob os auspícios da Sociedade de Colonização Americana, depois de passar por um rigoroso programa de formação cristã e munido da mais absoluta firmeza de caráter" (PHILLIPS, 2011. p. 9). 0 regresso que, para ele pode significar o retorno às origens ou resgate identitário, acaba por lhe revelar a verdadeira face de sua condição: sujeito diaspórico colonizado.

A partir do momento em que Nash se vê novamente em território africano, assume o papel de estrangeiro na própria pátria, pois, não consegue encontrar nenhum tipo de identificação com o lugar. Após uma narrativa introdutória, onde o leitor toma 
conhecimento da história do retorno de Nash, o capítulo passa a ser tomado por uma série de cartas enviadas por ele a seu ex-senhor, ora retratando sua situação em terra africana, ora procurando entender os motivos que levaram seu mestre a bani-lo e a não responder suas cartas.

Ele se sente dividido, pois mesmo vinculado ao local de sua origem, não se vê como pertencente àquela cultura: "Essa Libéria corrompeu meu ser, transformando-me de bom cavalheiro cristão que deixou sua casa, nesse pagão que o senhor não reconheceria" (PHILLIPS, 2011, p. 43). Além disso, busca o tempo todo justificativas para compreender os motivos que levaram seu ex-senhor a rejeitá-lo, como se nota nesse trecho: “... o senhor parece relutar em se corresponder comigo. Cheguei à conclusão que o senhor me repudiou por algum motivo cuja origem talvez seja algum tipo de vergonha". (PHILLIPS, 2011, p. 30). 0 status de estrangeiro no local de origem e a rejeição do local de acolhimento fazem com que Nash permaneça no entre-lugar, causado pela sensação de não-pertencimento.

Aqui percebemos a reconfiguração da ideia de 'lar' trabalhada por Avtar Brah (1996), onde o sujeito percebe que o retorno a um lugar de origem, o resgate de raízes na pátria ou nação não é possível e sequer desejável. 0 indivíduo da diáspora habita mais de um lar ao mesmo tempo e não se sente totalmente confortável em nenhum deles, o que torna problemática a ideia de pertencimento.

Arrancado ainda criança da África, Nash sofre por não se identificar com o clima e as pessoas do continente, porém, também tem consciência de que aquela é sua cultura e, por isso, precisa ao menos suportá-la. Tal situação causa a fragmentação de sua personalidade e provoca a crise de dupla consciência presente em todo o capítulo. Há momentos em que, ao se referir aos países do continente africano, Nash apresenta uma visão idealizada: “A Libéria é um bom lugar para se morar. [...] Uma pessoa de cor pode viver em plena liberdade aqui, pois não existe preconceito racial e todos os homens são livres e iguais" (PHILLIPS, 2011, p. 15). Em outras situações, se refere aos nativos como "um povo extremamente maldoso nesse país escuro e tenebroso" (PHILLIPS, 2011, p. 24). São nítidos nesses trechos os sintomas do sujeito diaspórico marcado pelo nãopertencimento: por vezes, Nash sente-se como um cidadão que regressa à pátria e se identifica com ela e outras vezes, como um intruso vivendo em um ambiente selvagem, prestes a ser devorado. 
A relação com os Estados Unidos, país onde fora comprado por Edward, acentua ainda mais o seu não-pertencimento. Educado segundo os costumes cristãos, por um lado, Nash demonstra toda a gratidão e subserviência ao colonizador: "Agradeço a Deus por o senhor ter tido a bondade de pegar a mim, uma criança tola, das mãos de meus pais e me criar em sua própria residência, mais como um filho do que como um servo" (PHILLIPS, 2011, p. 17). Por outro lado, tem consciência de que é um sujeito banido, impossibilitado de regressar ao que considerava seu lar: "Meu coração sofreu profundamente com a escolha do senhor de ignorar meu pedido de voltar aos Estados Unidos" (PHILLIPS, 2011, p. 30).

No decorrer do capítulo podemos notar com nitidez que, apesar da busca pela identificação com o continente africano, Nash fragmenta sua personalidade ao vestir a máscara do colonizador. Suas ações que imitam as de seu ex-senhor, a adesão à religião dominante na metrópole e o olhar outremizante que ele lança sobre os nativos da África, tratando-os como incultos e pagãos, destacam sua busca pela identificação com o dominador. Entretanto, o olhar desse dominador revela-lhe sua negritude, sua condição de colonizado, o que lhe coloca no entre-lugar.

Nash é, no romance, duplamente rejeitado. Pelo continente africano, ao ser vendido pelo pai e pelo continente americano ao ser banido por Edward. Sua identidade em trânsito, é marcada pela sensação de não-pertencimento. Através desse personagem, Philips nos apresenta uma visão dicotômica do sujeito diaspórico. Seu destino é sempre permanecer no entre-lugar: entre a África e a América, entre o cristão e o pagão, entre o cidadão e o estrangeiro, entre o selvagem e o civilizado.

O capítulo se encerra com um questionamento de Edward a respeito do retorno de Nash a seu local de origem: "O que poderia ter acontecido com a alma cristã de Nash Williams para fazê-lo aceitar uma vida que certamente até aqueles pagãos consideravam desprezível?" (PHILLIPS, 2011, p. 49). A resposta a esse questionamento é dada ao leitor no desenrolar de todo o capítulo. Nash, habitando ao mesmo tempo, dois lares diametralmente opostos, não encontra um centro e, por isso, não consolida a ideia de pertencimento. Até a morte, sua identidade permanece cindida e o Atlântico torna-se o símbolo dessa cisão devido à constante peregrinação, em seu curso, da personagem diaspórica. 


\subsection{Martha, traumas da dispersão violenta}

O terceiro capítulo do romance, intitulado $O$ Oeste, narra a travessia de Martha, a segunda irmã, pelos caminhos do Oeste americano no século XIX. Também vendida como escrava por seu pai, ela se vê violentamente separada do marido e do filho, o que a coloca em uma situação duplamente traumática: a escravidão em terra estrangeira e o rompimento radical com os laços familiares.

Após a conquista da liberdade, já em idade avançada e viajando em caravanas que seguem para o Oeste, ela se torna uma das pioneiras na colonização desta região do país: "A idade já estava cobrando seu preço e a atrite tomava conta de todas as partes do seu corpo. Ela seria uma pioneira na marcha para o Oeste" (PHILLIPS, 2011, p. 51). Seu objetivo maior está em reencontrar o marido e a filha e reconstruir os laços familiares quebrados pela diáspora forçada.

Importante notar que Phillips situa a personagem (mulher, negra, em idade avançada) em um ambiente essencialmente masculino e branco - o dos pioneiros mostrando sua contribuição ao processo de formação cultural do oeste americano. É um modo encontrado pelo autor para demonstrar a importância e a influência dos movimentos diaspóricos, principalmente dos negros africanos, na formação cultural nos caminhos do Atlântico.

A conquista da liberdade não livra a personagem dos traumas sofridos pela dispersão, mas funciona como um incentivo ao resgate de laços rompidos. É por isso que ela novamente se coloca em curso, em busca da solução para os traumas sofridos, tanto pela reminiscência do abandono pelo pai quanto pela brusca separação com o marido e a filha.

A história de Martha é a história da travessia, o resgate no presente do que lhe foi arrancado no passado. Ela busca se libertar, não somente dos horrores da escravidão, mas também do peso da outremização, de ser tratada como mero objeto. Sendo assim, ao partir em busca da família, ela quer resgatar a própria identidade:

Ela nunca mais seria leiloada. (Nunca). Nunca mais mudaria de nome. (Nunca). Nunca mais seria propriedade de outra pessoa. (Não, senhor; nunca). Olhou para trás e correu. (Sem olhar para trás, garota). E então, mais tarde, viu a alvorada se anunciar com todo seu vigor, e uma ofegante Martha foi descansar embaixo de um enorme salgueiro (PHILLIPS, 2011, p. 56). 
Martha é, no romance, o símbolo da formação cultural que transcende a homogeneidade das fronteiras. Ao se tornar pioneira na colonização do oeste americano ela denota a importância do sujeito diaspórico na construção identitária de todos os povos que circundam o Atlântico. Após se libertar da escravidão e se colocar em trânsito novamente para resgate de seus laços familiares, a personagem reflete sobre as perdas e ganhos de sua nova condição, seu novo status social.

Até o momento de se dedicar à aventura da busca, Martha, assim como os outros escravos, são tratados como meros objetos. A objetificação, tão marcante no colonialismo, está muito presente na caracterização da personagem até o momento de sua partida: "O senhor jamais teria nos vendido. Digo isso à minha filha apavorada. Os escravos. Os animais da fazenda. Os móveis da casa. As ferramentas. Tudo vai ser vendido - nessa ordem" (PHILLIPS, 2011, p. 53). Entretanto, a partir do momento em que se rompem os grilhões e Martha se coloca em curso, inicia a busca pela identidade e, em consequência, o status de sujeito. Muito mais do que simplesmente reencontrar familiares, Martha realiza um encontro consigo mesma, analisa suas perdas e ganhos nos (des) caminhos do Atlântico e reivindica a condição de sujeito da própria história, mesmo que fragmentado.

A objetificação causada pela colonização e os laços cortados violentamente pelos horrores da escravidão cedem espaço ao processo de reconstrução do sujeito marcado pela peregrinação ao Oeste. É o que Gilroy (2001) muito bem definiu como formação identitária constituída em trânsito, o indivíduo que, no entre-lugar, constrói sua personalidade e ganha status de sujeito.

Portanto, a passagem da escravidão à liberdade, o intercurso pelos caminhos do Atlântico e do oeste americano e o resgate de laços quebrados pela colonização tornam Martha figura importante ao debate sobre a diáspora. Sua aventura simboliza a dura caminhada em direção ao reconhecimento como sujeito: "Martha Randolph não vai lavar mais nada hoje. Nada de tanques, nem de ferros de passar. E também não vai cozinhar. Martha vai passar o dia inteiro dormindo" (PHILLIPS, 2011, p. 66).

A peregrinação em busca dos laços familiares permite a Martha sonhar, criar perspectiva de futuro e transformar-se de objeto a sujeito. É no sonho que ela reencontra um lar nos braços da filha, "uma negra alta, forte e de certo prestígio social" 
(PHILLIPS, 2011, p. 65). Sua personalidade diaspórica até então cindida, fragmentada, cede espaço à sensação de pertencimento, marcada pela vontade de estar junto de familiares e conquistada graças ao empenho na trajetória, afinal, "ela tinha uma alma que peregrinara até o Oeste e encontrara o seu habitat natural no colo da filha" (PHILLIPS, 2011, p. 66). A personagem, assim, torna-se símbolo da resistência no complexo movimento diaspórico africano.

\subsection{Travis, fragmentação do sujeito}

As personagens centrais de $A$ travessia do rio passam por diferentes sensações provocadas pela diáspora forçada. Enquanto Nash experimenta o não-pertencimento e Martha vive a fundo a ideia de objetificação e perda, Travis, o terceiro irmão, luta para manter um amor diante das circunstância da guerra. Travis é um soldado do exército norte-americano que, por ocasião da Segunda Guerra Mundial, é locado em uma pequena aldeia britânica. Nessa aldeia, conhece Joyce, uma inglesa branca e casada que sofre nas mãos de um marido irresponsável e violento. Devido à prisão do marido de Joyce e a consequente separação do casal, Travis inicia um relacionamento com a jovem inglesa, casando-se e tendo um filho com ela. Em campo de batalha, Travis é morto na costa italiana sem conhecer o próprio filho.

Esse capítulo do romance, intitulado Em algum lugar da Inglaterra, é escrito em forma de diário, onde podemos acompanhar, paralelamente, as consequências da diáspora na vida de Travis e o desenrolar dos conflitos internacionais causados pela grande guerra. A preocupação de Phillips não é mencionar os grandes acontecimentos que marcaram o contexto, com seus heróis e vilões, mas retratar o que acontece subjetivamente, nos descaminhos do protagonista, com suas expectativas e frustrações. Trata-se de um capítulo em que fica evidente a fragmentação da narrativa, onde as diversas idas e vindas formam um mosaico que se reflete no esfacelamento do próprio personagem:

Quase chorei quando o vi descer do trem. Ele parecia ter a espessura de uma porta e estava exausto. Não tinha mais aquela firmeza nas passadas. Não tinha mais alegria no rosto. Todo mundo ficou olhando pare ele. Acho que devem ter sentido pena dele, curvado sob o peso daquela mochila nas costas. Parecia ser o homem mais triste do mundo. [...] Quando ele veio até mim caminhando pela 
plataforma escura, com os passos curtos e aqueles ombros caídos, pude ver o quanto ele estava estraçalhado. Tinha grandes olheiras sob os olhos e já não fazia a barba fazia vários dias. (PHILLIPS, 2011, p. 228).

Percebe-se no trecho acima as marcas da fragmentação causada pela diáspora forçada. Travis, assim como os irmãos, não tem direito a uma residência fixa. Sua história é realizada em trânsito e, nesse transitar, marca a vida e a cultura de outras pessoas assim como coleciona perdas e se dilacera. Ele é um negro do exército americano e, como tal, sofre com os horrores da discriminação:

\footnotetext{
Ele me contou que bateram com tanta força que ele achou que seus rins fossem explodir. [...] Quando o levaram para o acampamento, fizeram um relato de que ele estava bêbado [...] Fiquei horrorizada quando ele me contou isso, mas ele parecia achar tudo muito natural. Me disse que o Exército só gostava deles para fazer faxinas e coisas do gênero. (PHILLIPS, 2011, p. 201).
}

Junte-se à discriminação por parte do exército de seu país a discriminação de classes devido a seu envolvimento com Joyce, branca e inglesa, como se pode notar pela opinião de Len, seu primeiro marido: "Antes de sair, disse que eu era uma traidora de minha classe. Que no que lhe dizia respeito eu não era melhor que uma prostituta comum" (PHILLIPS, 2011, p. 217). Além disso, as relações entre Inglaterra e Estados Unidos, devido à guerra estavam abaladas e, por isso, ao casar-se, Travis não poderia levar a esposa inglesa para o país norte-americano: "Ele já tinha dito que nós não poderíamos morar juntos nos Estados Unidos. Não era permitido" (PHILLIPS, 2011, p. 228). Por outro lado, esse trecho também se refere às políticas proibitivas do casamento ou uniões inter-raciais nos EUA. Essa política teve seu auge no século $\mathrm{XX}$, com os preconceitos raciais e sociais (representados pela proibição de qualquer manifestação cultural, voto, participação política, entre outros) foram elevados à categoria de normatização máxima na maioria dos estados americanos.

Assim como no caso de Martha, a temática do rompimento com os laços familiares também está presente na história de Travis. Mandado à Itália, por ocasião da guerra, Travis deixa Joyce grávida na Inglaterra. 0 filho que nasceria jamais conheceria o pai e a mãe, vendo-se sozinha após receber o telegrama que lhe comunicava a morte do marido, decide dar o filho para adoção: 
Mais tarde quando recebi o telegrama depois que a guerra terminou, a mulher de casaco azul veio me visitar. [...] Você vai ficar melhor, querida, se outra pessoa cuidar dele. [...] E então nós fomos sensatos, eu e meu filho. Meu filho que nunca pediu para eu entregá-lo para a mulher de casaco azul e cachecol marrom. (PHILLIPS, 2011, p. 232).

Caryl Phillips, ao retratar Travis marcado profundamente pela diáspora, com identidade fragmentada, faz com que sua história ganhe contornos heroicos, como os do herói trágico Édipo, condenado pelo destino e fadado a nunca abandonar sua trajetória, mesmo que siga para sua própria destruição. 0 mesmo se pode afirmar em relação a Nash e Martha. A travessia pelas águas do Atlântico não transformou a vida das personagens em uma sucessão de perdas e fracassos, mas transformou-as em sujeitos diaspóricos, alçando-os ao patamar de heróis, pioneiros construtores da civilização cultural moderna, ou, pelo menos aqueles que mantêm sua identidade, ou a constroem, seja através do encontro de um equilíbrio (no caso de Martha) ou de sua negação (no caso de Nash).

Travis reflete, no movimento diaspórico, a imagem do desengano em relação às suas expectativas. Na construção narrativa proposta por Phillips, composta de idas e vindas em um mosaico de datas e acontecimentos aleatórios, encontra-se uma personagem marcada pela fragmentação. Saído da África e criado entre os Estados Unidos, a Inglaterra e a Itália, Travis não consegue consolidar em sua trajetória a ideia de lar e pertencimento. A incompletude marca sua existência porque, em todos os locais do Atlântico pelos quais ele circula, é sempre obrigado a deixar para trás algo essencial (o pai, a esposa, o filho). É ele, portanto, o símbolo da identidade africana desenraizada, fragmentada pelo movimento diaspórico.

\section{Considerações finais}

Caryl Phillips, em A travessia do rio, resgata um tema que já havia trabalhado em outras obras: as consequências do deslocamento. Ele propõe uma reflexão sobre a trajetória diaspórica de uma família marcada pelas agruras da escravidão. Mais do que isso, foge do discurso unilateral, permeando seu texto de múltiplos narradores que oscilam de acordo com o objeto narrado. Como resultado, há uma junção primorosa de conteúdo e forma numa obra peculiar sobre o multiculturalismo. 
A história de Nash, Martha e Travis adquire contornos romanescos, graças à capacidade imaginativa do autor, trazendo detalhes sobre a escravidão, muitas vezes omitidos pelos documentos oficiais. Mais do que isso, retrata as transformações do mundo, entre os séculos XVIII, XIX e XX, sobre o prisma da diáspora. Com capítulos que resgatam três faces distintas do movimento diaspórico africano, a saber, o pertencimento, o trauma e a fragmentação, o romance se fecha com uma exposição dos movimentos multiculturais provenientes da dispersão dos povos da África. O tambor que se ouve "na margem mais distante do rio" (PHILLIPS, 2011, p. 237) e o eco desse rufar levado pelo vento, "bem acima dos telhados, por cima da água, sobre a terra, sobre as copas das árvores" (PHILLIPS, 2011, p. 237), nada mais são do que a penetração da cultura africana nos caminhos do Atlântico.

Phillips encerra seu texto mostrando que a história de Nash, Martha e Travis é a história de um povo sobrevivente, símbolo da luta do negro no movimento diaspórico, povo esse que conseguiu influenciar a história ao redor do Atlântico, pela música, pela arte, pela literatura, pela política. As vozes desses sobreviventes são ouvidas constantemente nos diferentes territórios do Atlântico, seja na música (jazz, reggae, blues, calypso, samba), seja no som de um carnaval africano em Trinidad, Rio ou Nova Orleans ou ainda nas diversas manifestações socioculturais que ultrapassam fronteiras. A voz do sujeito diaspórico africano continua a gritar em busca do pertencimento e o Atlântico (esse rio que ceifa, transporta e transforma vidas) é elemento indispensável dessa busca.

Nash, Martha e Travis, mesmo tendo sentido a dor excruciante dos grilhões da escravidão, mesmo sofrendo na pele a angústia do abandono e do dilaceramento identitário, alcançaram a outra margem do rio. Portanto, juntos simbolizam os caminhos e descaminhos do movimento diaspórico africano e o Atlântico, palco dessa diáspora, é o responsável pela formação da identidade em trânsito, longe das concepções de identidade fixa e acabada.

\section{Referências}

BONICCI, Thomas. Conceitos-chave da teoria pós-colonial. Maringá: Eduem, 2005.

BRAH, Avtar. Cartographies of diaspora: Contesting Identities. New York: Routledge, 1996. 
BHABHA, Homi K. O local da cultura. Trad. Eliana L. L. Reis, Gláucia R. Gonçalves e Myriam Ávila. Belo Horizonte: Editora UFMG, 1998.

FANON, Frantz. Pele negra, máscaras brancas. Trad. Renato da Silveira. Salvador: EDUFBA, 2008.

GILROY, Paul. O Atlântico negro. Modernidade e dupla consciência. São Paulo: Editora 34, Rio de Janeiro: UCAM, 2001.

HALL, Stuart. Da Diáspora: identidades e mediações culturais. Trad. Adelaine La Guardia Resende; Ana Carolina Escosteguy; Ana Carolina Escosteguy et al. Belo Horizonte: Editora UFMG, 2003.

Identidade cultural na pós-modernidade. Trad. Tomaz Tadeu da Silva e Guacira Lopes Louro. Rio de Janeiro: DP\&A, 2005.

PHILIPS, Caryl. A Travessia do Rio. Trad. Gabriel Zide Neto. Rio de Janeiro: Record, 2011.

SANTOS, Eufrásia Cristina Meneses. Resenha: 0 Atlântico Negro. Revista de Antropologia, v. 45, n. 1. São Paulo, 2002.

SPIVAK, Gayatri Chacravorty. The Rani of Simur. In: BARKER, Francis et al. Europe and Its Others: Proceedings of the Essex Conference on the Sociology of Literature, Colchester, University of Essex, v.1, 1984.

WALTER, Roland. Transferência Interculturais: Notas sobre trans-cultura, multi-cultura, diásporas e encruzilhadas. Revista Sociopoética, João Pessoa, v. 1, n. 1, s.d.

Recebido em junho de 2014.

Aceito em novembro de 2014. 